PEMBELAJAR: Jurnal Ilmu Pendidikan, Keguruan, dan Pembelajaran

Volume 5 Nomor 1 April 2021

e-ISSN: 2549-9114 dan p-ISSN: 2549-9203

(Received: Februari-2021; Reviewed: Maert-2021; Published: April 2021)

DOI: https://doi.org/10.26858/pembelajar.v5i1.13279

\title{
Upaya Meningkatkan Disiplin Guru Dalam Kehadiran Mengajar Di Kelas Melalui Penerapan Reward And Punishment Di SMP Negeri 6 Dumai
}

\author{
${ }^{1}$ SMP Negeri 6 Dumai, Indonesia \\ Andi Efendi \\ Corresponding Email: melisayafrina@ymail.com
}

\begin{abstract}
Abstrak: $\quad$ Budaya sekolah merupakan hal yang positif yang harus dikembangkan, salah satunya adalah masalah kedisiplinan, termasuk disiplin para guru dalam kehadiran dikelas pada proses utamanya mengajar.Untuk meningkatkan disiplin para guru dapat diupayakan melalui bermacam-macam cara. Penelitian Tindakan Sekolah (PTS) ini, dilakukan tindakan berupa penerapan Reward and Punishment untuk para guru di SMP Negeri 6 Dumai, Kota Dumai. Penelitian ini dilakukan dalam dua siklus, dimana dari hasil penelitian dan analisa data, ternyata pada siklus kedua, kedisiplinan guru dalam kehadiran dikelas pada proses belajar mengajar meningkat dan memenuhi indikator yang telah ditetapkan sebesar $85 \%$. Dari hasil penelitian ini, dapat disimpulkan bahwa untuk meningkatkan disiplin guru dalam kehadiran dikelas pada kegiatan belajar mengajar dapat dilakukan dengan penerapan Reward and Punishment kepada guru.
\end{abstract}

Kata Kunci : Disiplin Guru, Penelitian Tindakan Sekolah

Abstract: $\quad$ School culture is a positive thing that must be developed, one of which is the problem of discipline, including the discipline of teachers in class attendance on main process of teaching. To improve the discipline of teachers, it could be pursued through a variety of ways. The School Action Research (PTS) was conducted in the application of Reward and Punishment for teachers in SMPN 6 Dumai, Dumai City. This research was conducted in two cycles, where from the results of research and data analysis, in second cycle teacher discipline in class attendance in teaching and learning process increased and fulfill the indicator which has been set at $85 \%$. From the results of this study, it could be concluded that to improve teacher discipline in class attendance at teaching and learning activities, it could be done by applying Reward and Punishment to teachers.

Keywords: Discipline of teachers, reward, punishment 


\section{PENDAHULUAN}

Peran guru dewasa ini, semakin besar dan tugasnya bertambah berat. Guru diharapkan mampu menanamkan dan menumbuhkan nilainilai positif dalam penguatan pendidikan karakter sebagai upaya mempersiapkan generasi yang cerdas, terampil dan takwa kepada Tuhan Yang Maha Esa.

Peranan guru selain sebagai seorang pengajar, guru juga berperan sebagai seorang pendidik. Pendidik adalah setiap orang yang dengan sengaja mempengaruhi orang lain untuk mencapai tingkat kemanusiaan yang lebih tinggi (Sutari Imam Barnado, 1989:44).

Keteladanan guru dapat dilihat dari perilaku guru sehari-hari baik dalam sekolah maupun diluar sekolah. Selain keteladanan guru, kedisiplinan juga menjadi salah satu hal yang penting untuk dimiliki oleh guru sebagai tolak ukur pengajar dan pendidik yang professional

Guru merupakan teladan untuk menjadi contoh atau model hidup bagi siswa sehingga diperlukan kedisiplinan dalam proses pembelajaran. Jika proses pembelajaran terjadi dengan baik maka perlu diberikan reward yang sesuai terhadap guru tersebut. Namun sebaliknya jika pembelajaran yang dilakukan oleh guru tidak sesuai dengan yang diharapkan, maka diperlukan punishment untuk memberikan efek jera terhadap guru tersebut.

Fakta di lapangan sering dijumpai di sekolah yaitu kurangnya disiplin seorang guru ketika memasuki kelas.

Berdasarkan uraian diatas penulis tertarik untuk melakukan penelitian tindakan sekolah dengan judul : "Upaya Meningkatkan Disiplin Guru dalam Kehadiran Mengajar di Kelas Melalui Penerapan Reward and Punishment di SMP Negeri 6 Dumai”.

Menurut Budiningsih (2005:4) pendidikan selain mengawetkan kebudayaan dan meneruskannya dari generasi ke generasi, akan tetapi juga diharapkan pendidikan ini dapat mengubah dan mengembangkan suatu peradaban sebagai inti pendidikan. Pendidikan menyediakan keterampilan yang sudah dikenal dan seharusnya dapat meramalkan berbagai jenis keterampilan dan kemahiran yang akan dating, dan sekaligus menemukan cara yang tepat dan cepat dikuasai oleh anak didik.

Begitu juga Sagala (2003:14) mengatakan bahwa kegiatan belajar mengajar tenaga guru merupakan suatu komponen yang penting dalam penyelenggaraan pendidikan. Guru sebagai pendidik adalah seseorang atau sekelompok orang yang berprofesi mengelola kegiatan belajar mengajar, serta seperangkat lainnya yang memungkinkan berlangsungnya kegiatan belajar mengajar lebih efektif. Berdasarkan atas tugas mengajarnya, maka dia harus mempunyai wewenang mengajar berdasarkan kualifikasi sebagai pengajar. Kedudukan guru dipahami demikian penting sebagai ujung tombak dalam pembelajaran dan pencapaian mutu hasil belajar peserta didik.

\section{METODE}

Pelaksanaan penelitian dilakukan di SMP Negeri 6 Dumai tahun ajaran 2019/2020 dengan jumlah 42 orang guru, terdiri atas 25 orang guru PNS dan 17 orang guru non PNS. Pendekatan yang digunakan dalam penelitian ini adalah pendekatan Kualitatif. Penelitian ini terdiri dari dua siklus.

Teknik pengumpulan data kualitatif ini, diperoleh dari observasi, wawancara, maupun pengumpulan data sekunder. Dimana observasi yang dilakukan yaitu mengamati implementasi kebijakan yang berkaitan dengan kedisiplinan guru dalam kehadiran di kelas pada kegiatan belajar mengajar meliputi : kehadiran guru di kelas, tingkat keterlambatan guru masuk kedalam kelas, dan ketepatan waktu meninggalkan kelas setelah pelajaran usai. Untuk tekhnik wawancara diperoleh data dari informan secara langsung. Sedangkan pengumpulan data sekunder diperoleh melalui dokumen-dokumen tertulis yang diyakini integritasnya karena mengambil dari berbagai sumber yang relevan dengan penelitian yaitu diperoleh dari hasil dialog bersama kolaborator, data base sekolah, dan lain lain.

\section{HASIL DAN PEMBAHASAN}

Penerapan tindakan sekolah ini diperoleh hasil yaitu :

Pada siklus 1, rekapitulasi tindak keterlambatan guru di kelas pada proses pembelajaran diperoleh data, sebanyak 2 orang guru terlambat kurang dari 5 menit, 8 orang guru terlambat masuk kelas kurang dari 10 menit, 5 orang guru terlambat masuk kelas 10 menit s.d. 15 menit dan 11 orang guru terlambat masuk kelas lebih dari 15 menit. Pada siklus 2, rekapitulasi tingkat keterlambatan guru di kelas pada proses pembelajaran diperoleh 


\section{Andi Efendi}

Upaya Meningkatkan Disiplin Guru Dalam Kehadiran Mengajar Di Kelas Melalui Penerapan Reward And Punishment Di Smp Negeri 6 Dumai

data, sebanyak 10 orang guru terlambat masuk kelas kurang dari 5 menit, 5 orang guru terlambat kurang dari 10 menit, 3 orang guru terlambat masuk kelas 10 menit s.d 15 menit, dan tidak ada satu orangpun guru yang terlambat masuk kelas lebih dari 15 menit.

Berdasarkan hasil dari kedua siklus tersebut, penulis mengambil kesimpulan bahwa tindakan yang dilaksanakan pada siklus kedua dinyatakan berhasil, karena terdapat peningkatan yang signifikan dimana kehadiran guru tepat waktu di dalam kelas,sudah mencapai tingkat waktu didalam kelas, sudah mencapai target yaitu 30,95 lebih dari 30\% jumlah guru. Sedangkan guru dengan keterlambatan kurang dari 5 menit sudah mencapai taerget yaitu lebih dari $60 \%$ tepatnya $61,90 \%$ sementara keterlambatan lebih dari 5 menit sampai dengan kurang dari 15 menit masing-masing $4,76 \%$ dan $2,39 \%$ artinya sudah mencapai target yaitu kurang dari 5\%.

\section{KESIMPULAN DAN SARAN}

Adapun kesimpulan penelitian ini adalah: (1) Penerapan tindakan Reward dan Punishment di SMP Negeri 6 Dumai dapat meningkatkan motivasi guru untuk lebih disiplin dalam proses kegiatan belajar mengajar; (2) Data yang diperoleh menunjukkan bahwa setelah diadakan penerapan tindakan berupa Rewards dan punishment, guru yang terlambnat lebih dari 15 menit adalah 0 , guru yang terlambat kurang dari 10 s.d. 15 menit sebanyak 3 orang guru, guru yang terlambat kurang dari 10 menit sebanyak 5 orang guru, dan guru yang terlambat kurang dari 5 menit sebanyak 10 orang guru. Sehingga dapat dikatakan penerapan rewards dan punishment dapat meningkatkan disiplin guru dalam proses belajar mengajar.

Saran dari penelitian adalah: (1) Seluruh kepala sekolah disarankan melakukan penerapan Rewards dan Punishment untuk meningkatkan kedisiplinan guru dalam proses belajar mengajar di kelas; (2) Seluruh guru dalam melaksanakan tugas agar dapat meningkatkan kedisiplinan sebagai bentuk keprofesionalisme dalam proses belajar mengajar.

\section{DAFTAR PUSTAKA}

Akhmad Sudrajat, (2010) Manfaat Prinsip dan Asas Pengembangan Budaya Sekolah. [On Line]. Tersedia http://akhmadsudrajat.wordpress.com/2010/03/0

4/manfaat- $\quad$ prinsip-dan-asas-
pengembangan-budaya-sekolah/
Oktober 2010].

Arikunto, S. (2002). Prosedur Penelitian Suatu Pendekatan Praktek. Jakarta:Rineka Cipta

Aunurrahman. (2009). Belajar dan Pembelajaran. Bandung:Alfabeta

Bambang Nugroho. (2006). Reward dan Punishment. Bulletin CiptaKarya Departemen Pekerjaan Umum Edisi No. 6/IV/Juni 2006

Departemen Pendidikan Nasional. (2003). Undang-undang Nomor 20 Tahun 2003 Tentang Sistem Pendidikan Nasional. Jakarta:Depdiknas

Megawangi, Ratna. (2007). Membangun SDM Indonesia Melalui Pendidikan Holistik Berbasis Karakter. Jakarta:Indonesian Heritage Foundation

Subagio. (2010). Kompetensi Guru dalam Meningkatkan Mutu Pembelajaran [On Line]. Tersedia : http://subagiosubagio.blogspot.com/2010/03/kompet ensi-guru-dalam- meningkatkanmutu.html

Sumarso. (2010). Upaya Meningkatkan Disiplin Guru Dalam Kehadiran Mengajar Dikelas Melalui Penerapan Reward And Punishment Di Smp Negeri 3 Mandalawangi Kabupaten Pandeglang

Syamsul Hadi, (2009). Kepemimpinan Pembelajaran, Makalah Disampaikan pada Sosialisasi Akuntabilitas Kinerja Kepala Sekolah Dalam Inovasi Pembelajaran. Departemen Pendidikan Nasional, Direktorat Jenderal Peningkatan Mutu Pendidik dan Tenaga Kependidikan, Direktorat Tenaga Kependidikan 